Syracuse University

SURFACE

Center for Policy Research

Maxwell School of Citizenship and Public Affairs

9-2010

\title{
A Dynamic Spatial Panel Data Approach to the German Wage Curve
}

Badi H. Baltagi

Syracuse University

Uwe Blien

Otto-Friedrich-University of Bamberg

Katja Wolf

D-90327 Nuremberg, Germany-0049-911/1793035

Follow this and additional works at: https://surface.syr.edu/cpr

Part of the Economics Commons

\section{Recommended Citation}

Baltagi, Badi H.; Blien, Uwe; and Wolf, Katja, "A Dynamic Spatial Panel Data Approach to the German Wage Curve" (2010). Center for Policy Research. 165.

https://surface.syr.edu/cpr/165

This Working Paper is brought to you for free and open access by the Maxwell School of Citizenship and Public Affairs at SURFACE. It has been accepted for inclusion in Center for Policy Research by an authorized administrator of SURFACE. For more information, please contact surface@syr.edu. 


\title{
Center for Policy Research
}

Working Paper No. 126

\author{
A Dynamic Spatial Panel Data \\ Approach to the German Wage Curve
}

\author{
Badi H. Baltagi, Uwe Blien \\ and Katja Wolf
}

\author{
Center for Policy Research \\ Maxwell School of Citizenship and Public Affairs \\ Syracuse University \\ 426 Eggers Hall \\ Syracuse, New York 13244-1020 \\ (315) 443-3114 | Fax (315) 443-1081 \\ e-mail: ctrpol@syr.edu
}

September 2010

$\$ 5.00$

Up-to-date information about CPR's research projects and other activities is available from our World Wide Web site at www-cpr.maxwell.syr.edu. All recent working papers and Policy Briefs can be read and/or printed from there as well. 


\title{
CENTER FOR POLICY RESEARCH - Fall 2010
}

\author{
Christine L. Himes, Director \\ Maxwell Professor of Sociology
}

Associate Directors

\author{
Margaret Austin \\ Associate Director \\ Budget and Administration
}

\author{
Douglas Wolf \\ Gerald B. Cramer Professor of Aging Studies \\ Associate Director, Aging Studies Program
}

\begin{abstract}
John Yinger
Professor of Economics and Public Administration Associate Director, Metropolitan Studies Program
\end{abstract}

\section{SENIOR RESEARCH ASSOCIATES}

Badi Baltagi

Robert Bifulco.

Economics

Leonard Burman ..Public Administration/Economics

Kalena Cortes.

Education

Thomas Dennison

Public Administration

William Duncombe

Public Administration

Gary Engelhardt

Economics

Deborah Freund .. Public Administration/Economics

Madonna Harrington Meyer

William C. Horrace Sociology

Duke Kao Economics

Eric Kingson Economics

Sharon Kioko Social Work

Thomas Kniesner

Jeffrey Kubik

Andrew London
Len Lopoo

Amy Lutz.

Jerry Miner......

Jan Ondrich

John Palmer

David Popp....

Gretchen Purser

Christopher Rohlfs

Stuart Rosenthal.

Ross Rubenstein

Perry Singleton.

Margaret Usdansky

Michael Wasylenko

Jeffrey Weinstein

Janet Wilmoth.
Public Administration .. Sociology Economics Economics Public Administration Public Administration .. Sociology Economics Economics Public Administration .Economics Sociology Economics Economics Sociology

\section{GRADUATE ASSOCIATES}

Charles Alamo

Kanika Arora

Samuel Brown

Christian Buerger

Il Hwan Chung.

Alissa Dubnicki

Andrew Friedson

Virgilio Galdo....

Jenna Harkabus

Clorise Harvey....

Biff Jones.

Hee Seung Lee
Public Administration

.Public Administration

Public Administration

Public Administration

Public Administration Economics Economics Economics Public Administration Public Administration Public Administration Public Administration
Chong $\mathrm{Li}$ Jing $\mathrm{Li}$ Allison Marier

Qing Miao ..... Wael Moussa Casey Muhm Kerri Raissian Morgan Romine Amanda Ross. Natalee Simpson Liu Tian. Ryan Yeung
Economics Economics Economics Public Administration . Economics Public Administration Public Administration Public Administration Economics Sociology Public Administration .Public Administration

\section{STAFF}

Kelly Bogart. Administrative Secretary Martha Bonney.......Publications/Events Coordinator Karen Cimilluca...................... Office Coordinator Kitty Nasto. Administrative Secretary
Candi Patterson. Roseann Presutti. Mary Santy.....
Computer Consultant Administrative Secretary Administrative Secretary 


\section{Abstract:}

A wage curve is a decreasing function of wages on the regional unemployment rate. Most empirical studies on the wage curve ignore possible spatial interaction effects between the regions which are the primary units of research. This paper reconsiders the western German wage curve with a special focus on the geography of labour markets. Spillovers between regions are taken into account. The paper tests whether the unemployment rate in the larger surrounding region also affects wages. In addition, agglomeration effects and effects of local monopsony are assessed.

The main data base is a random sample of 974,179 employees observed over the period 1980-2004 and covering 326 NUTS3 units (districts). This rich data set is used to estimate a dynamic wage curve according to the two-step approach of Bell et al. (2002). In the first step one controls for individual heterogeneity and in the second step one allows for spatial effects of unemployment across regions on wages. We check the sensitivity of this wage elasticity to various spatial weight matrices as well as allowing for the endogeneity of unemployment. We also estimate the wage elasticity for various population groups.

JEL: J30, C23, R10

Keywords: Wage Curve, regional labour markets, spatial panel

Badi H. Baltagi* Syracuse University, Center for Policy Research and Department of Economics, Syracuse, New York 13244-1020-(315) 443-1081and University of Leicester, Leicester, U.K. E-mail: bbaltagi@maxwell.syr.edu

Uwe Blien and Katja Wolf Institute for Employment Research (IAB), D-90327 Nuremberg, Germany-0049-911/1793035 and \& Otto-Friedrich-University of Bamberg (Blien) E-mail: uwe.blien@iab.de

* The authors would like to thank Wolfgang Dauth and Phan thi Hong Van (both IAB) for excellent research assistance. We also thank two anonymous referees and the guest editors Francesco Moscone and Giuseppe Arbia for their helpful comments and suggestions. 


\section{Introduction}

A wage curve is a decreasing function of wages on the regional unemployment rate. Starting with the seminal contributions of Blanchflower and Oswald (1994, see also 2005) many researchers have been able to find this relationship using data from over 40 countries including western economies as well as a number of developing and transitional economies. One of the limitations in this extensive research on the wage curve concerns the treatment of regions as independent units. Empirical regions of one nation, however, are connected not only by trade flows but also by labour mobility and by commuting relationships. In the standard approach on the wage curve either individual or regional panel data are used. To control for unobserved heterogeneity, regional fixed effects are usually included. However, this does not account for the spatial correlation which is introduced by the close relationship between the regions. This paper tackles this problem by using a spatial approach to the wage curve. Spillovers between regions are taken into account. The paper tests whether only the unemployment rate of a small area is relevant or whether the unemployment rate in the larger surrounding region also affects wages. In addition, the paper investigates whether agglomeration effects and influences of regional monopsony are relevant for the wage curve mechanism.

For the purpose of this study it is important to use a comprehensive data base. Previous research has shown that the wage curve at least in Germany is a rather "shy guy", which can only be properly studied when detailed data for a long time period is available.

\section{Previous studies}

Previous studies which used a spatial approach to German data include Buettner (1999), Pannenberg and Schwarze (2000) and Longhi, Nijkamp and Poot (2006). Buettner (1999) seems to have been the first to estimate a spatial panel model for Germany using maximum likelihood methods. However, he did not include the log of the regional unemployment rate as is usual in the wage curve approach. Instead he used the inverse of the regional unemployment rate and had to evaluate the wage elasticities at various levels of unemployment. Using data on manufacturing wages, Buettner found a small elasticity varying between -0.04 at an unemployment rate of $2.5 \%$ to -0.005 at an unemployment rate of $18 \%$. Pannenberg, and Schwarze (2000) considered a regional panel for 74 regions of West Germany observed over the period 1985-1994. They estimated a dynamic wage curve and checked its robustness with respect to spatial correlation in regional unemployment. They found it impossible to accurately identify the effects of spatial unemployment rates due to its multicollinearity with the local unemployment rate.

More recently, Longhi, Nijkamp and Poot (2006) estimated a wage curve with spatially weighted unemployment rates included as an extra regressor. They estimated separate models for regions with different degrees of 
agglomeration. They found that the wage curve is more pronounced in rural areas than in core cities. This is explained by the fact that labour demand in these rural areas may be characterised by higher degrees of monopsony (see Manning 2003 \& 2004).

Our paper differs from those of Buettner (1999), Longhi et al. (2006) and others (like Pannenberg, Schwarze 2000) in two important respects. We use individual data based on a random sample of 974,179 employees observed over the period 1980-2004 and covering 326 NUTS3 units, whereas these papers used average wage data across German regions. Our richer data set allows us to estimate a dynamic wage curve using the two-step approach of Bell et al. (2002). In the first step we control for individual heterogeneity and in the second step we allow for spatial effects of unemployment across regions on wages. Baltagi et al. (2009) used this data set to estimate a dynamic wage curve but did not account for any spatial effects. The latter is the focus of this paper. We check the sensitivity of this wage elasticity to various spatial weight matrices as well as allowing for endogeneity of unemployment. Buettner (1999) and Longhi et al. (2006) included square terms of unemployment and the latter study even included an interaction term of spatial weighted unemployment with local unemployment. Their spatial weight matrix is based upon the Euclidean distance between regions.

The Longhi et al. (2006) paper is the closest to our work but it is based on average wage data. Their control variables include the share of women in employment; the share of workers employed in firms with less than 20 employees; the share of less educated workers; and the share of workers employed in agriculture in region $j$ at time $t$. Without spatial weighted unemployment, they find a wage elasticity of -0.02 at an average unemployment rate of $7.6 \%$, and -0.04 at a maximum rate of unemployment of $20.6 \%$. Instrumenting for endogeneity of unemployment by its lagged value, they get a lower wage elasticity of - 0.01 at an average unemployment rate of $7.6 \%$, and this becomes positive at higher unemployment rates.

The inclusion of spatial weighted unemployment is an important device to test the effects of a hierarchy of regions. Based on efficiency wage models as well as wage negotiation approaches, the theory of the wage curve gives no hints for the proper delineation of regional labour markets. In our case the regional units we observe are sufficiently small to allow us to test for the effects of the unemployment rate of neighbouring regions. Local firms may be restricted in their wage setting behavior if large labor markets are close by. Whether these neighboring labor markets influence the behavior of the local firm is the subject of our empirical study. In contrast to previous empirical studies, we are able to estimate this wage elasticity for various population groups (including young versus old, men versus women, less educated versus highly educated, German natives versus foreigners). These groups have different competitive positions in the labour market, and they may be affected differently by local monopsonies. 


\section{Empirical model}

Following Bell et al. (2002) and Baltagi et al. (2009), we analyse the wage curve in two steps. In the first step a model is estimated for each region separately to adjust wages for individual composition effects. In the second step these adjusted wages are used to estimate the wage curve. To control for individual heterogeneity a `first stage panel' wage equation is estimated for each region $j$ as follows:

$$
\begin{aligned}
& W_{i j t}=\alpha_{i}+\alpha_{j t}+\sum_{k=1}^{K} X_{i j t k} \beta_{j k}+\varepsilon_{i j t} \\
& i=1, \ldots, N \quad j=1, \ldots, J \quad \text { and } \quad t=1, \ldots, T .
\end{aligned}
$$

where $W_{i j t}$ is the log wage rate of individual $i$ observed in region $j$ in period $t$. $X_{i j t k}$ is a set of $k=1, \ldots, K$ measured characteristics of individual $i$ (such as age, age ${ }^{2}$, gender, education, occupation etc.), $\alpha_{i}$ is the $i$-th individual effect, $\alpha_{j t}$ is the time effect for region $j$, and $\varepsilon_{i j t}$ is the remainder error term. The estimate of $\alpha_{j t}$, obtained by running a panel regression with fixed effects for each region $j$, is denoted by the `composition corrected wage' in the regional panel model. We skip the alternative approach that Bell et al. (2002) used, which is a 'first stage cross-section' wage equation, because the first stage panel provides a better control for individual heterogeneity. In the second stage regression, Bell et al. (2002) include a dynamic formulation given by:

$$
\alpha_{j t}=\mu_{j}+\lambda_{t}+\beta_{1} \alpha_{j t-1}+\beta_{2} u_{j t}+\sum_{j=2}^{J}\left(\gamma_{j}^{\prime} D_{j}\right) t+v_{j t}
$$

where $u_{j t}$ is the log of the regional unemployment rate in region $j$ in period $t . D_{j}$ is a region dummy. The number of observations for this regression is JT. We include specific time trends to capture systematic trends in regionspecific wage pressure.

Baltagi et al. (2009) estimated this model using fixed effects allowing unemployment to be endogenous and instrumenting it by its lagged values. Of course, fixed effects in a dynamic panel model is subject to a finite sample bias of order $(1 / \mathrm{T})$ which is 25 in this case. Baltagi et al. (2009) found that the lagged wage coefficient estimate is significant, i.e. $\beta_{1}$ is significantly different from zero, rejecting the static wage equation in favour of a dynamic specification. This estimate of $\beta_{1}$ was far from unity (a maximum of 0.6 with a very small standard error of 0.01). Therefore the unit root hypothesis implied by the pure Phillips curve can be rejected. The shortrun and long-run elasticities of wages with respect to unemployment were relatively small but significant. For all workers, they estimated the effect of regional unemployment on wages to be -0.016 in the short run and - 
0.037 in the long run. These elasticities were slightly smaller when they did not instrument for unemployment. It is interesting to note that Bell et al. (2002) obtain a coefficient that is about three times larger for the UK than the one Baltagi et al. (2009) found for Germany.

One point of departure of this paper from the approach chosen by Bell et al. (2002) and Baltagi et al. (2009) is the inclusion of a spatially extended version of the unemployment rate. Our regional units are quite small; we have 326 representing western Germany in total. Wages could therefore be expected to depend not only on supply and demand in a worker’s home region but also on the labour market situation of neighbouring regions.

$$
\alpha_{j t}=\mu_{j}+\lambda_{t}+\beta_{1} \alpha_{j t-1}+\beta_{2} u_{j t}+\beta_{3} G u_{t}+\sum_{j=2}^{J}\left(\gamma_{j}{ }^{\prime} D_{j}\right) t+v_{j t}
$$

The matrix $G$ is a spatial weight matrix which symbolizes the connections between regions. It can be constructed in various ways which are discussed later. $G$ is of dimension $J \times J$ and collects the regional weights $g_{k j}$. Its main diagonal elements are zero and it is row-normalised. This means that each row sums to one. $u_{t}$ is a vector collecting all the regional unemployment rates $u_{j t}$. A spatially weighted unemployment regressor $\left(G u_{t}\right)$ is therefore included to show how the labour market conditions of the neighbouring regions influence local wages.

\section{Data}

In this section we briefly give an overview on our data base. Further details are given in the Appendix of Baltagi, et al. (2009). The IAB Employment Sample is a random sample which is not our exclusive property but may be used by other researchers as well, since it is a scientific use file. It consists of 974,179 individuals drawn from the population of employees who are covered by social insurance and observed over the period 1980-2004. This group comprises over 80\% of all employment in Germany, since it does not include civil servants and workers with very low incomes. The total number of observations in our sample is 9,188,532 covering all 326 districts of western Germany. These districts are the administrative units and are the smallest regions for which unemployment rates are available.

However, the data suffers from two limitations. The first limitation is that wages are censored for groups with high incomes. For example, in 1989, this threshold was a monthly income of 3,119 Euros. Multiple imputation methods (Rubin 1987 \& 1996) using panel data on a shorter time period showed only very small changes in the wage curve results. The second limitation is that no exact working hours are reported in the data. Hence, only people working full-time were included in our data base. In spite of these limitations, the data represents a rich source of information, with many variables like age, gender, occupation, industry and qualification. In exploiting this data base, regional heterogeneity can be controlled for, and the wage information is reliable, 
since this data is used as the basis for pensions paid. No problem of recall or reporting is encountered as is the case in population surveys.

\section{Main results on the dynamic wage curve with spatial effects}

Table 1 shows the results for the dynamic German wage curve with spatial effects on unemployment. We use a contiguity matrix for $G$, i.e., the nonzero elements of $G$ represent regions that have a common border. The upper half of the table gives the results of the standard fixed effects estimator which is instrumented in the lower half by lagged values of the unemployment rate, see Bell et al. (2002) and Baltagi et al. (2009). Only the lagged wage coefficient, the short-run, the long-run and the spatial lag effects of unemployment are reported. ${ }^{1}$ In the first step regressions given by (1), we include age, age ${ }^{2}$, gender, four worker qualification categories, six employment status categories, fourteen occupational categories, thirty-one industry categories and nine establishment size categories. The results on spatial unemployment for all employed workers given in column 1 of Table 1 are not significant at the 5\%-level. Local unemployment, i.e. unemployment in one’s own region is the only important labour market indicator. This holds true for different population groups, including males and females; younger and older workers; German and foreign workers; low and highly qualified workers shown in the remaining columns of Table 1 . To save space, we focus on the fixed IV results in the remainder of the discussion. In all cases, the lagged wage coefficient estimates are significant, ranging between (0.443 and 0.596). This rejects the static wage equation in favour of a dynamic specification. Blanchflower and Oswald (1994) and Card (1995) find that for the U.S., men’s wages are more sensitive to the unemployment rate than women's wages. This is also true for western Germany. The short run elasticity is -0.020 for males (column 2), as compared to -0.012 for females (column 3). It is -0.043 and -0.025 respectively in the long run. In western Germany, we find that younger workers (below the age of 30) have a significantly higher wage elasticity than older workers (above the age of 45 ) -0.020 as compared to -0.013 in the short run, and -0.048 and -0.027 respectively in the long run (see columns 4 and 5 of Table 1). Foreigners have lower bargaining power due to their migration background than Germans, see (Ottaviano, Peri 2006, Bruecker, Jahn 2010). This is confirmed by our results. The short-run effect is -0.016 in the case of Germans (column 6) and -0.036 in the case of foreigners (column 7). This corresponds to long-run effects of -0.037 and -0.070 respectively. For less qualified workers, the short-run elasticity is -0.007 (column 8) as compared to -0.020 for highly qualified workers (column 9). The long run estimates are -0.013 and -0.039, respectively. However, these estimates are not statistically significant.

\footnotetext{
1 The results on the control variables are available upon request from the authors.
} 
Table 1: All regions

German dynamic wage curve by type of worker including spatial effects of unemployment The IAB Employment Sample: 1980-2004

\begin{tabular}{|c|c|c|c|c|c|c|c|c|c|}
\hline & 1 & 2 & 3 & 4 & 5 & 6 & 7 & 8 & 9 \\
\hline & ALL & MALE & FEM & YOUNG & OLD & GERMAN & FOREIGN & LowQual. & HighQual \\
\hline Fixed Effects & $N=7824$ & & & & & & & & \\
\hline$W_{i j t-1}$ & $\begin{array}{c}0.5812 \\
(0.0134)\end{array}$ & $\begin{array}{c}0.5642 \\
(0.0142 \\
)\end{array}$ & $\begin{array}{c}0.5587 \\
(0.0122)\end{array}$ & $\begin{array}{c}0.5959 \\
(0.0125)\end{array}$ & $\begin{array}{l}0.5559 \\
(0.012)\end{array}$ & $\begin{array}{c}0.5815 \\
(0.0131)\end{array}$ & $\begin{array}{c}0.5177 \\
(0.0301)\end{array}$ & $\begin{array}{c}0.4891 \\
(0.0107)\end{array}$ & $\begin{array}{c}0.4425 \\
(0.0720)\end{array}$ \\
\hline Short-Run $u_{j t}$ & $\begin{array}{l}-0.0111 \\
(0.0014)\end{array}$ & $\begin{array}{c}-0.0121 \\
(0.0015 \\
)\end{array}$ & $\begin{array}{l}-0.0078 \\
(0.0022)\end{array}$ & $\begin{array}{l}-0.0133 \\
(0.0024)\end{array}$ & $\begin{array}{r}-0.0094 \\
(0.001)\end{array}$ & $\begin{array}{l}-0.0106 \\
(0.0014)\end{array}$ & $\begin{array}{l}-0.0266 \\
(0.0054)\end{array}$ & $\begin{array}{l}-0.0128 \\
(0.0022)\end{array}$ & $\begin{array}{l}-0.0079 \\
(0.0057)\end{array}$ \\
\hline Long-Run $u_{j t}$ & $\begin{array}{l}-0.0264 \\
(0.0032)\end{array}$ & $\begin{array}{c}-0.0279 \\
(0.0035 \\
) \\
\end{array}$ & $\begin{array}{l}-0.0178 \\
(0.0049)\end{array}$ & $\begin{array}{l}-0.0329 \\
(0.0060)\end{array}$ & $\begin{array}{r}-0.0212 \\
(0.003)\end{array}$ & $\begin{array}{l}-0.0253 \\
(0.0033)\end{array}$ & $\begin{array}{l}-0.0551 \\
(0.0104)\end{array}$ & $\begin{array}{l}-0.0250 \\
(0.0048)\end{array}$ & $\begin{array}{l}-0.0142 \\
(0.0104)\end{array}$ \\
\hline Spatial $u^{*} j t$ & $\begin{array}{l}-0.0006 \\
(0.0017)\end{array}$ & $\begin{array}{c}0.0001 \\
(0.0018 \\
)\end{array}$ & $\begin{array}{l}-0.0032 \\
(0.0027)\end{array}$ & $\begin{array}{l}-0.0026 \\
(0.0030)\end{array}$ & $\begin{array}{c}-0.0012 \\
(0.001)\end{array}$ & $\begin{array}{l}-0.0009 \\
(0.0017)\end{array}$ & $\begin{array}{c}0.0177 \\
(0.0068)\end{array}$ & $\begin{array}{l}-0.0006 \\
(0.0027)\end{array}$ & $\begin{array}{c}0.0057 \\
(0.0048)\end{array}$ \\
\hline \multicolumn{10}{|l|}{ IV $(F E)^{a}$} \\
\hline$W_{i j t-1}$ & $\begin{array}{c}0.5527 \\
(0.0109)\end{array}$ & $\begin{array}{c}0.05311 \\
(0.0109 \\
)\end{array}$ & $\begin{array}{c}0.5351 \\
(0.0109)\end{array}$ & $\begin{array}{c}0.5767 \\
(0.0108)\end{array}$ & $\begin{array}{l}0.5183 \\
(0.010)\end{array}$ & $\begin{array}{c}0.5532 \\
(0.0109)\end{array}$ & $\begin{array}{c}0.4856 \\
(0.0120)\end{array}$ & $\begin{array}{c}0.4633 \\
(0.0117)\end{array}$ & $\begin{array}{c}0.4790 \\
(0.0106)\end{array}$ \\
\hline Short-Run $u_{j t}$ & $\begin{array}{l}-0.0175 \\
(0.0030)\end{array}$ & $\begin{array}{c}-0.0201 \\
(0.0033 \\
) \\
\end{array}$ & $\begin{array}{l}-0.0118 \\
(0.0052)\end{array}$ & $\begin{array}{l}-0.0201 \\
(0.0059)\end{array}$ & $\begin{array}{r}-0.0129 \\
(0.003)\end{array}$ & $\begin{array}{l}-0.0163 \\
(0.0030)\end{array}$ & $\begin{array}{l}-0.0361 \\
(0.0135)\end{array}$ & $\begin{array}{l}-0.0067 \\
(0.0055)\end{array}$ & $\begin{array}{l}-0.0201 \\
(0.0134)\end{array}$ \\
\hline Long-Run $u_{j t}$ & $\begin{array}{l}-0.0391 \\
(0.0045)\end{array}$ & $\begin{array}{c}-0.0429 \\
(0.0080 \\
) \\
\end{array}$ & $\begin{array}{l}-0.0253 \\
(0.0063)\end{array}$ & $\begin{array}{l}-0.0476 \\
(0.0079)\end{array}$ & $\begin{array}{r}-0.0267 \\
(0.002)\end{array}$ & $\begin{array}{l}-0.0365 \\
(0.0032)\end{array}$ & $\begin{array}{l}-0.0702 \\
(0.0259)\end{array}$ & $\begin{array}{l}-0.0125 \\
(0.0102)\end{array}$ & $\begin{array}{l}-0.0385 \\
(0.0257)\end{array}$ \\
\hline Spatial $u^{*} j t$ & $\begin{array}{c}0.0020 \\
(0.0034)\end{array}$ & $\begin{array}{c}0.0037 \\
(0.0038 \\
)\end{array}$ & $\begin{array}{l}-0.0029 \\
(0.0061)\end{array}$ & $\begin{array}{c}0.0034 \\
(0.0068)\end{array}$ & $\begin{array}{r}-0.0013 \\
(0.003)\end{array}$ & $\begin{array}{c}0.0014 \\
(0.0035)\end{array}$ & $\begin{array}{c}0.0272 \\
(0.0157)\end{array}$ & $\begin{array}{l}-0.0096 \\
(0.0064)\end{array}$ & $\begin{array}{c}0.0097 \\
(0.0156)\end{array}$ \\
\hline
\end{tabular}

a The IV models instrument unemployment and spatial unemployment by its lags, see Bell et al. (2002). 
Table 2: Type 1 - Regions with core cities

German dynamic wage curves by type of workers including spatial effects of unemployment The IAB Employment Sample: 1980-2004

\begin{tabular}{|c|c|c|c|c|c|c|c|c|}
\hline & 1 & 2 & 3 & 4 & 5 & 6 & 7 & 8 \\
\hline & ALL & $\begin{array}{c}\text { ALL } \\
\text { Spat.Ex. }\end{array}$ & MALE & $\begin{array}{l}\text { MALE } \\
\text { Spat Ex. }\end{array}$ & FEMALE & $\begin{array}{l}\text { FEMALE } \\
\text { Spat. Ex. }\end{array}$ & GERMAN & $\begin{array}{l}\text { GERMAN } \\
\text { Spat. Ex. }\end{array}$ \\
\hline \multicolumn{9}{|l|}{ Fixed Effects } \\
\hline$W_{i j t-1}$ & $\begin{array}{c}0.5618 \\
(0.0164) \\
\end{array}$ & $\begin{array}{c}0.5614 \\
(0.0164) \\
\end{array}$ & $\begin{array}{c}0.5502 \\
(0.0165) \\
\end{array}$ & $\begin{array}{c}0.5502 \\
(0.0216) \\
\end{array}$ & $\begin{array}{c}0.5086 \\
(0.0173) \\
\end{array}$ & $\begin{array}{c}0.5080 \\
(0.0212) \\
\end{array}$ & $\begin{array}{c}0.5613 \\
(0.0216) \\
\end{array}$ & $\begin{array}{c}0.5603 \\
(0.0216) \\
\end{array}$ \\
\hline Short-Run $u_{j t}$ & $\begin{array}{l}-0.0116 \\
(0.0014) \\
\end{array}$ & $\begin{array}{l}-0.0098 \\
(0.0020) \\
\end{array}$ & $\begin{array}{l}-0.0134 \\
(0.0016) \\
\end{array}$ & $\begin{array}{l}-0.0131 \\
(0.0023) \\
\end{array}$ & $\begin{array}{l}-0.0093 \\
(0.0023) \\
\end{array}$ & $\begin{array}{l}-0.0040 \\
(0.0034) \\
\end{array}$ & $\begin{array}{l}-0.0108 \\
(0.0014) \\
\end{array}$ & $\begin{array}{l}-0.0085 \\
(0.0020) \\
\end{array}$ \\
\hline Long-Run $u_{j t}$ & $\begin{array}{l}-0.0266 \\
(0.0030)\end{array}$ & $\begin{array}{l}-0.0223 \\
(0.0046)\end{array}$ & $\begin{array}{l}-0.0297 \\
(0.0033)\end{array}$ & $\begin{array}{c}-0.0292 \\
(0.0050)\end{array}$ & $\begin{array}{l}-0.0189 \\
(0.0046)\end{array}$ & $\begin{array}{c}-0.0082 \\
(0.0070)\end{array}$ & $\begin{array}{l}-0.0247 \\
(0.0031)\end{array}$ & $\begin{array}{l}-0.0194 \\
(0.0047)\end{array}$ \\
\hline Spatial $u^{*} j t$ & & $\begin{array}{l}-0.0031 \\
(0.0025)\end{array}$ & & $\begin{array}{l}-0.0004 \\
(0.0028)\end{array}$ & & $\begin{array}{l}-0.0088 \\
(0.0041)\end{array}$ & & $\begin{array}{l}-0.0038 \\
(0.0025) \\
\end{array}$ \\
\hline \multicolumn{9}{|l|}{ IV $(F E)^{a}$} \\
\hline$W_{i j t-1}$ & $\begin{array}{c}0.5210 \\
(0.0186)\end{array}$ & $\begin{array}{c}0.5228 \\
(0.0186) \\
\end{array}$ & $\begin{array}{c}0.5021 \\
(0.0186) \\
\end{array}$ & $\begin{array}{c}0.5040 \\
(0.0185)\end{array}$ & $\begin{array}{c}0.4935 \\
(0.0189) \\
\end{array}$ & $\begin{array}{c}0.4934 \\
(0.0189) \\
\end{array}$ & $\begin{array}{c}0.5228 \\
(0.0186) \\
\end{array}$ & $\begin{array}{c}0.5231 \\
(0.0185) \\
\end{array}$ \\
\hline Short-Run $u_{j t}$ & $\begin{array}{c}-0.0196 \\
(0.0031) \\
\end{array}$ & $\begin{array}{c}-0.0154 \\
(0.0052) \\
\end{array}$ & $\begin{array}{l}-0.0214 \\
(0.0034) \\
\end{array}$ & $\begin{array}{l}-0.0187 \\
(0.0059) \\
\end{array}$ & \begin{tabular}{|l|}
-0.0178 \\
$(0.0049)$ \\
\end{tabular} & $\begin{array}{l}-0.0115 \\
(0.0086) \\
\end{array}$ & \begin{tabular}{c|}
-0.0182 \\
$(0.0031)$ \\
\end{tabular} & $\begin{array}{l}-0.0130 \\
(0.0053) \\
\end{array}$ \\
\hline Long-Run $u_{j t}$ & $\begin{array}{l}-0.0409 \\
(0.0060) \\
\end{array}$ & $\begin{array}{l}-0.0322 \\
(0.0107) \\
\end{array}$ & $\begin{array}{l}-0.0429 \\
(0.0066)\end{array}$ & $\begin{array}{l}-0.0377 \\
(0.0117) \\
\end{array}$ & $\begin{array}{l}-0.0305 \\
(0.0096)\end{array}$ & $\begin{array}{l}-0.0210 \\
(0.0168)\end{array}$ & $\begin{array}{l}-0.0382 \\
(0.0062)\end{array}$ & $\begin{array}{l}-0.0273 \\
(0.0109) \\
\end{array}$ \\
\hline Spatial $u^{*} j t$ & & $\begin{array}{l}-0.0056 \\
(0.0057)\end{array}$ & & $\begin{array}{c}-0.0024 \\
(0.0065) \\
\end{array}$ & & $\begin{array}{l}-0.0106 \\
(0.0094) \\
\end{array}$ & & $\begin{array}{l}-0.0077 \\
(0.0058)\end{array}$ \\
\hline
\end{tabular}

\begin{tabular}{|c|c|c|c|c|c|c|c|c|c|c|}
\hline & 9 & 10 & 11 & 12 & 13 & 14 & 15 & 16 & 17 & 18 \\
\hline & YOUNG & $\begin{array}{c}\text { YOUNG } \\
\text { Spat. } \\
\text { Ex. }\end{array}$ & OLD & $\begin{array}{c}\text { OLD } \\
\text { Spat. } \\
\text { Ex. }\end{array}$ & FOREIGN & $\begin{array}{c}\text { FOREIGN } \\
\text { Spat. Ex. }\end{array}$ & LowQual. & $\begin{array}{l}\text { LowQual. } \\
\text { Spat. Ex. }\end{array}$ & HighQual. & $\begin{array}{l}\text { HighQual. } \\
\text { Spat. Ex. }\end{array}$ \\
\hline \multicolumn{11}{|l|}{ Fixed Effects } \\
\hline$W_{i j t-1}$ & $\begin{array}{c}0.6062 \\
(0.0161) \\
\end{array}$ & $\begin{array}{c}0.6062 \\
(0.0198) \\
\end{array}$ & $\begin{array}{c}0.5531 \\
(0.0164) \\
\end{array}$ & $\begin{array}{c}0.5517 \\
(0.0224) \\
\end{array}$ & $\begin{array}{c}0.4265 \\
(0.0367) \\
\end{array}$ & $\begin{array}{c}0.4210 \\
(0.0367) \\
\end{array}$ & $\begin{array}{c}0.4470 \\
(0.0182) \\
\end{array}$ & $\begin{array}{c}0.4463 \\
(0.0275) \\
\end{array}$ & $\begin{array}{c}0.4762 \\
(0.0431) \\
\end{array}$ & $\begin{array}{c}0.4756 \\
(0.0432) \\
\end{array}$ \\
\hline Long-Run $u_{j t}$ & $\begin{array}{l}-0.0369 \\
(0.0063) \\
\end{array}$ & $\begin{array}{l}-0.0283 \\
(0.0103) \\
\end{array}$ & \begin{tabular}{|c|}
-0.0193 \\
$(0.0034)$ \\
\end{tabular} & $\begin{array}{l}-0.0116 \\
(0.0051) \\
\end{array}$ & $\begin{array}{l}-0.0235 \\
(0.0074) \\
\end{array}$ & $\begin{array}{l}-0.0451 \\
(0.0103) \\
\end{array}$ & $\begin{array}{l}-0.0221 \\
(0.0045) \\
\end{array}$ & $\begin{array}{l}-0.0269 \\
(0.0075) \\
\end{array}$ & \begin{tabular}{|l|}
-0.0274 \\
$(0.0075)$ \\
\end{tabular} & $\begin{array}{l}-0.0190 \\
(0.0112) \\
\end{array}$ \\
\hline Spatial $u^{*} j t$ & & $\begin{array}{l}-0.0057 \\
(0.0049)\end{array}$ & & $\begin{array}{l}-0.0057 \\
(0.0028)\end{array}$ & & $\begin{array}{c}0.0209 \\
(0.0077)\end{array}$ & & $\begin{array}{c}0.0044 \\
(0.0050)\end{array}$ & & $\begin{array}{l}-0.0073 \\
(0.0072)\end{array}$ \\
\hline Short-Run $u_{j t}$ & $\begin{array}{l}-0.0180 \\
(0.0060) \\
\end{array}$ & $\begin{array}{l}-0.0085 \\
(0.0104) \\
\end{array}$ & $\begin{array}{l}-0.0147 \\
(0.0034) \\
\end{array}$ & $\begin{array}{l}-0.0072 \\
(0.0058) \\
\end{array}$ & $\begin{array}{c}-0.0182 \\
(0.0093) \\
\end{array}$ & $\begin{array}{l}-0.0506 \\
(0.0167) \\
\end{array}$ & $\begin{array}{l}-0.0126 \\
(0.0054) \\
\end{array}$ & $\begin{array}{l}-0.0132 \\
(0.0095) \\
\end{array}$ & $\begin{array}{l}-0.0147 \\
(0.0085) \\
\end{array}$ & $\begin{array}{c}0.0168 \\
(0.0148) \\
\end{array}$ \\
\hline Long-Run $u_{j t}$ & $\begin{array}{l}-0.0426 \\
(0.0138)\end{array}$ & $\begin{array}{l}-0.0202 \\
(0.0243)\end{array}$ & $\begin{array}{l}-0.0301 \\
(0.0068)\end{array}$ & $\begin{array}{l}-0.0220 \\
(0.0119)\end{array}$ & $\begin{array}{l}-0.0303 \\
(0.0154) \\
\end{array}$ & $\begin{array}{c}-0.0824 \\
(0.0264)\end{array}$ & $\begin{array}{c}-0.0216 \\
(0.0092)\end{array}$ & $\begin{array}{l}-0.0227 \\
(0.0162)\end{array}$ & $\begin{array}{l}-0.0278 \\
(0.0160)\end{array}$ & $\begin{array}{c}0.0316 \\
(0.0320)\end{array}$ \\
\hline Spatial $u^{*} j t$ & & $\begin{array}{l}-0.0142 \\
(0.0113)\end{array}$ & & $\begin{array}{l}-0.0108 \\
(0.0065)\end{array}$ & & $\begin{array}{c}0.0540 \\
(0.0185)\end{array}$ & & $\begin{array}{c}0.0028 \\
(0.0105)\end{array}$ & & $\begin{array}{l}-0.0483 \\
(0.0164)\end{array}$ \\
\hline
\end{tabular}

a This instruments for unemployment and spatial unemployment by its lags, see Bell et al. (2002). 
The finding that spatial unemployment is insignificant in the dynamic wage curve for western Germany is an interesting result, because it may indicate that the relevant actors in the labour market are myopic. They do not care about labour market conditions only some kilometres away. Another explanation for the lack of influence of the surrounding areas in the labour market situation is the existence of commuting and migration cost. Workers do not respond to spatial differences in the unemployment rate, because there is a cost in doing this. Firms know this and do not take the unemployment rate of a larger area into account in their wage setting behaviour.

Longhi et al. (2006, page 708) discuss whether the spatial effect of unemployment depend upon the business cycle. They expect that in phases of high unemployment, firms will pay the wage negotiated at the level of sectors (as it is done normally in Germany - see Buettner 1999). However, if unemployment is low, firms would be forced to pay a wage premium to motivate and hire workers. A wage gap between negotiated and effectively paid wages will develop, which should also be influenced by local labour market conditions. Therefore, the wage curve should be more pronounced in favourable times. Applying the same argument to the effect of spatial unemployment, it can be concluded that this effect should also depend on the business cycle. To test this hypothesis an interaction term is included in the regressions on the wage curve. It is generated by interacting the growth rate of the economy with either local or spatial unemployment. Our results show that this interaction effect is small and insignificant. This is not reported here to save space but it is available upon request from the authors.

\section{Important spatial aspects of the wage curve}

Following Longhi et al. (2006), Tables 2-4 give results for different types of regions. The idea here is that in regions with large agglomerations workers have a choice of firms, whereas in the rural areas they may depend on one employer. In the rural area case, the wage curve can be expected to be more pronounced than in regions with core cities. The background for this research is that the extent of monopsony (see Manning 2003 \& 2004) in the labour market depends on the nature of the respective region. Whereas outright monopsony is rare in a modern economy, different degrees of monopsonistic competition can be expected from different types of regions. The crucial interacting variables concern the very number of firms located in an area and the accessibility of the area. Both variables are correlated with the existence of agglomerations and their size.

To classify regions we use a typology which is widely applied in empirical research and was originally created

by a German research institute, the Federal Office for Building and Regional Planning (BBR). There, regions are classified into 9 different types. Like Longhi et al. (2006), we use a coarser classification based on three classes: 
regions with large core cities (Table 2), regions with conurbational features (Table 3) and regions belonging to the rural country (Table 4).

Table 3: Type 2 - Regions with conurbational features

German dynamic wage curves by type of workers including spatial effects of unemployment

The IAB Employment Sample: 1980-2004

\begin{tabular}{|l|c|c|c|c|c|c|c|c|}
\hline & 1 & 2 & 3 & 4 & 5 & 6 & 7 & 8 \\
\hline & ALL & $\begin{array}{c}\text { ALL } \\
\text { Spat Ex. }\end{array}$ & MALE & $\begin{array}{c}\text { MALE } \\
\text { Spat Ex. }\end{array}$ & FEMALE & $\begin{array}{c}\text { FEMALE } \\
\text { Spat. Ex. }\end{array}$ & GERMAN & $\begin{array}{c}\text { GERMAN } \\
\text { Spat. Ex. }\end{array}$ \\
\hline Fixed Effects & & & & & & & & \\
\hline$W_{i j t-1}$ & 0.5894 & 0.5896 & 0.5647 & 0.5647 & 0.5764 & 0.5763 & 0.5895 & 0.5898 \\
$(0.0144)$ & $(0.0145)$ & $(0.0149)$ & $(0.0218)$ & $(0.0148)$ & $(0.0181)$ & $(0.0203)$ & $(0.0203)$ \\
\hline Short-Run $u_{j t}$ & -0.0126 & -0.0130 & -0.0137 & -0.0138 & -0.0106 & -0.0097 & -0.0124 & -0.0131 \\
& $(0.0011)$ & $(0.0017)$ & $(0.0012)$ & $(0.0023)$ & $(0.0021)$ & $(0.0032)$ & $(0.0013)$ & $(0.0021)$ \\
\hline Long-Run $u_{j t}$ & -0.0306 & -0.0318 & -0.0314 & -0.0317 & -0.0250 & -0.0229 & -0.0302 & -0.0319 \\
& $(0.0032)$ & $(0.0050)$ & $(0.0032)$ & $(0.0052)$ & $(0.0050)$ & $(0.0075)$ & $(0.0032)$ & $(0.0051)$ \\
\hline Spatial $u^{*} j t$ & & 0.0009 & & 0.0002 & & -0.0015 & & 0.0021 \\
& & $(0.0023)$ & & $(0.0028)$ & & $(0.0041)$ & & $(0.0026)$ \\
\hline & & & & & & & & \\
\hline IV (FE) & & & & & & & & \\
\hline$W_{i j t-1}$ & & & & & & & \\
\hline Short-Run $u_{j t}$ & -0.0132 & -0.0155 & -0.0151 & -0.0176 & -0.0125 & -0.0126 & -0.0130 & -0.0155 \\
& $(0.0023)$ & $(0.0040)$ & $(0.0024)$ & $(0.0043)$ & $(0.0040)$ & $(0.0071)$ & $(0.0023)$ & $(0.0041)$ \\
\hline Long-Run $u_{j t}$ & -0.0310 & -0.0366 & -0.0328 & -0.0383 & -0.0279 & -0.0281 & -0.0305 & -0.0365 \\
$(0.0051)$ & $(0.0092)$ & $(0.0051)$ & $(0.0091)$ & $(0.0088)$ & $(0.0159)$ & $(0.0052)$ & $(0.0093)$ \\
\hline \multirow{2}{*}{ Spatial $u^{*} j t$} & & 0.0038 & & 0.0043 & & 0.0001 & & 0.0041 \\
& & $(0.0051)$ & & $(0.0041)$ & & $(0.0092)$ & & $(0.0051)$ \\
\hline
\end{tabular}

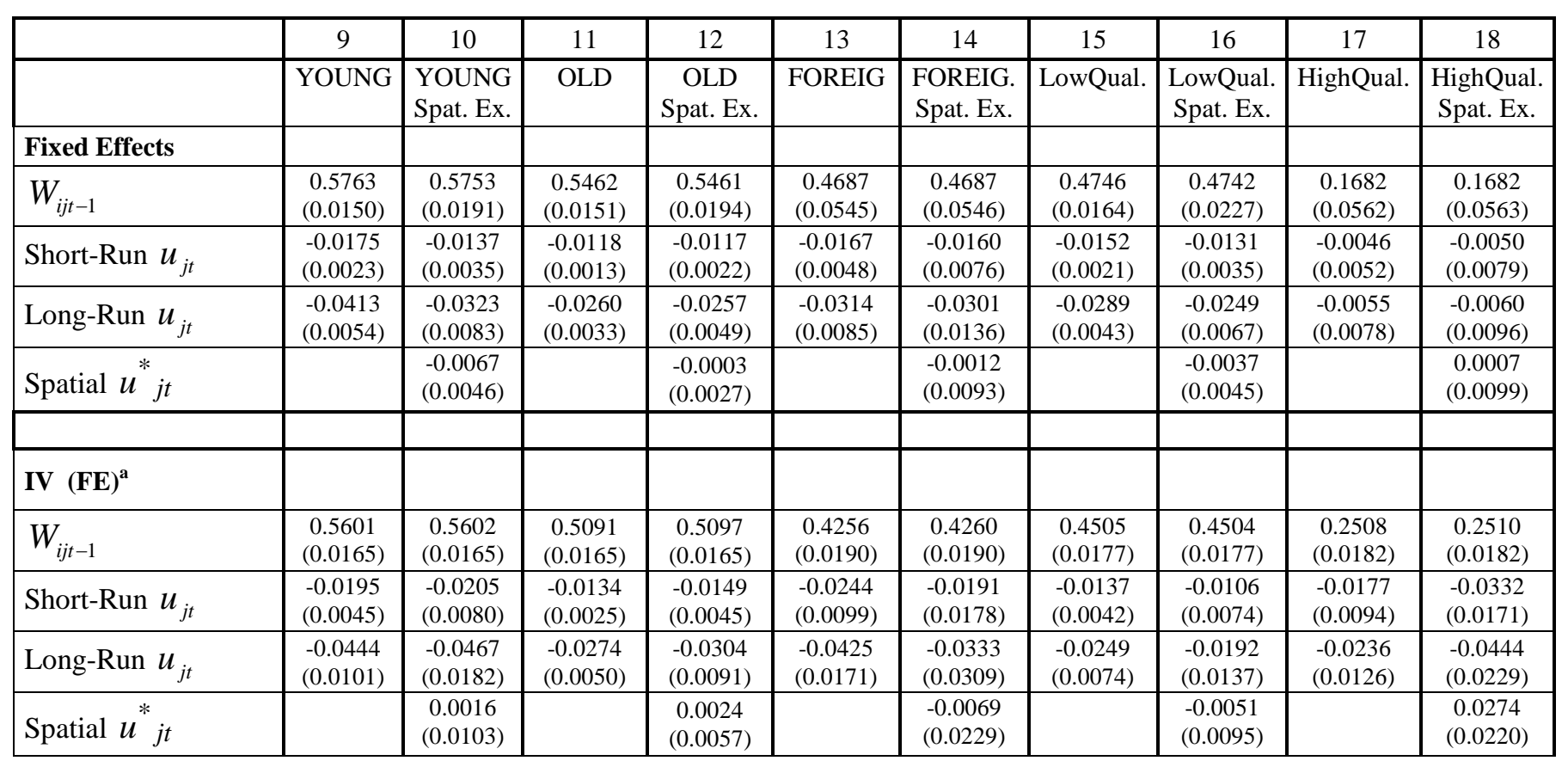

a This instruments for unemployment and spatial unemployment by its lags, see Bell et al. (2002). 
Table 4: Type 3 - Regions in the rural country

German dynamic wage curves by type of workers including spatial effects of unemployment The IAB Employment Sample: 1980-2004

\begin{tabular}{|c|c|c|c|c|c|c|c|c|}
\hline & 1 & 2 & 3 & 4 & 5 & 6 & 7 & 8 \\
\hline & ALL & $\begin{array}{c}\text { ALL } \\
\text { Spat.Ex. }\end{array}$ & MALE & $\begin{array}{l}\text { MALE } \\
\text { Spat Ex. }\end{array}$ & FEMALE & $\begin{array}{l}\text { FEMALE } \\
\text { Spat. Ex. }\end{array}$ & GERMAN & $\begin{array}{l}\text { GERMAN } \\
\text { Spat. Ex. }\end{array}$ \\
\hline \multicolumn{9}{|l|}{ Fixed Effects } \\
\hline$W_{i j t-1}$ & $\begin{array}{c}0.5650 \\
(0.0223) \\
\end{array}$ & $\begin{array}{c}0.5643 \\
(0.0223) \\
\end{array}$ & $\begin{array}{c}0.5407 \\
(0.0229) \\
\end{array}$ & $\begin{array}{c}0.5400 \\
(0.0336) \\
\end{array}$ & $\begin{array}{c}0.5688 \\
(0.0223) \\
\end{array}$ & $\begin{array}{c}0.5689 \\
(0.0246) \\
\end{array}$ & $\begin{array}{c}0.5691 \\
(0.0275) \\
\end{array}$ & $\begin{array}{c}0.5681 \\
(0.0277) \\
\end{array}$ \\
\hline Short-Run $u_{j t}$ & $\begin{array}{c}-0.0110 \\
(0.0021) \\
\end{array}$ & $\begin{array}{l}-0.0098 \\
(0.0028) \\
\end{array}$ & $\begin{array}{l}-0.0107 \\
(0.0023) \\
\end{array}$ & $\begin{array}{l}-0.0093 \\
(0.0034) \\
\end{array}$ & $\begin{array}{l}-0.0074 \\
(0.0039) \\
\end{array}$ & $\begin{array}{l}-0.0082 \\
(0.0051) \\
\end{array}$ & $\begin{array}{l}-0.0106 \\
(0.0021) \\
\end{array}$ & $\begin{array}{l}-0.0091 \\
(0.0031) \\
\end{array}$ \\
\hline Long-Run $u_{j t}$ & $\begin{array}{c}-0.0252 \\
(0.0050)\end{array}$ & $\begin{array}{l}-0.0224 \\
(0.0073)\end{array}$ & $\begin{array}{c}-0.0234 \\
(0.0052)\end{array}$ & $\begin{array}{c}-0.0202 \\
(0.0076)\end{array}$ & $\begin{array}{l}-0.0172 \\
(0.0089)\end{array}$ & $\begin{array}{l}-0.0190 \\
(0.0118)\end{array}$ & $\begin{array}{l}-0.0246 \\
(0.0050)\end{array}$ & $\begin{array}{l}-0.0210 \\
(0.0074)\end{array}$ \\
\hline Spatial $u^{*} j t$ & & $\begin{array}{l}-0.0023 \\
(0.0034)\end{array}$ & & $\begin{array}{l}-0.0028 \\
(0.0043)\end{array}$ & & $\begin{array}{c}0.0015 \\
(0.0063)\end{array}$ & & $\begin{array}{l}-0.0029 \\
(0.0040)\end{array}$ \\
\hline \multicolumn{9}{|l|}{ IV (FE)a } \\
\hline$W_{i j t-1}$ & $\begin{array}{c}0.5151 \\
(0.0257) \\
\end{array}$ & $\begin{array}{c}0.5144 \\
(0.0260) \\
\end{array}$ & $\begin{array}{c}0.5028 \\
(0.0254) \\
\end{array}$ & $\begin{array}{c}0.5022 \\
(0.0257) \\
\end{array}$ & $\begin{array}{c}0.5375 \\
(0.0246) \\
\end{array}$ & $\begin{array}{c}0.5373 \\
(0.0246) \\
\end{array}$ & $\begin{array}{c}0.5221 \\
(0.0255) \\
\end{array}$ & $\begin{array}{c}0.5222 \\
(0.0258) \\
\end{array}$ \\
\hline Short-Run $u_{j t}$ & $\begin{array}{l}-0.0229 \\
(0.0057) \\
\end{array}$ & $\begin{array}{l}-0.0323 \\
(0.0084) \\
\end{array}$ & $\begin{array}{l}-0.0238 \\
(0.0060) \\
\end{array}$ & $\begin{array}{l}-0.0353 \\
(0.0089) \\
\end{array}$ & $\begin{array}{l}-0.0133 \\
(0.0101) \\
\end{array}$ & $\begin{array}{l}-0.0158 \\
(0.0149) \\
\end{array}$ & $\begin{array}{l}-0.0202 \\
(0.0057) \\
\end{array}$ & $\begin{array}{l}-0.0291 \\
(0.0084) \\
\end{array}$ \\
\hline Long-Run $u_{j t}$ & $\begin{array}{l}-0.0473 \\
(0.0112) \\
\end{array}$ & $\begin{array}{l}-0.0665 \\
(0.0167) \\
\end{array}$ & $\begin{array}{l}-0.0478 \\
(0.0117) \\
\end{array}$ & $\begin{array}{l}-0.0709 \\
(0.0173) \\
\end{array}$ & $\begin{array}{l}-0.0287 \\
(0.0215) \\
\end{array}$ & $\begin{array}{c}-0.0342 \\
(0.0318) \\
\end{array}$ & $\begin{array}{l}-0.0422 \\
(0.0114) \\
\end{array}$ & $\begin{array}{l}-0.0609 \\
(0.0170)\end{array}$ \\
\hline Spatial $u^{*} j t$ & & $\begin{array}{c}0.0164 \\
(0.0091) \\
\end{array}$ & & $\begin{array}{c}0.0202 \\
(0.0097) \\
\end{array}$ & & $\begin{array}{c}0.0040 \\
(0.0164) \\
\end{array}$ & & $\begin{array}{c}0.0158 \\
(0.0091) \\
\end{array}$ \\
\hline
\end{tabular}

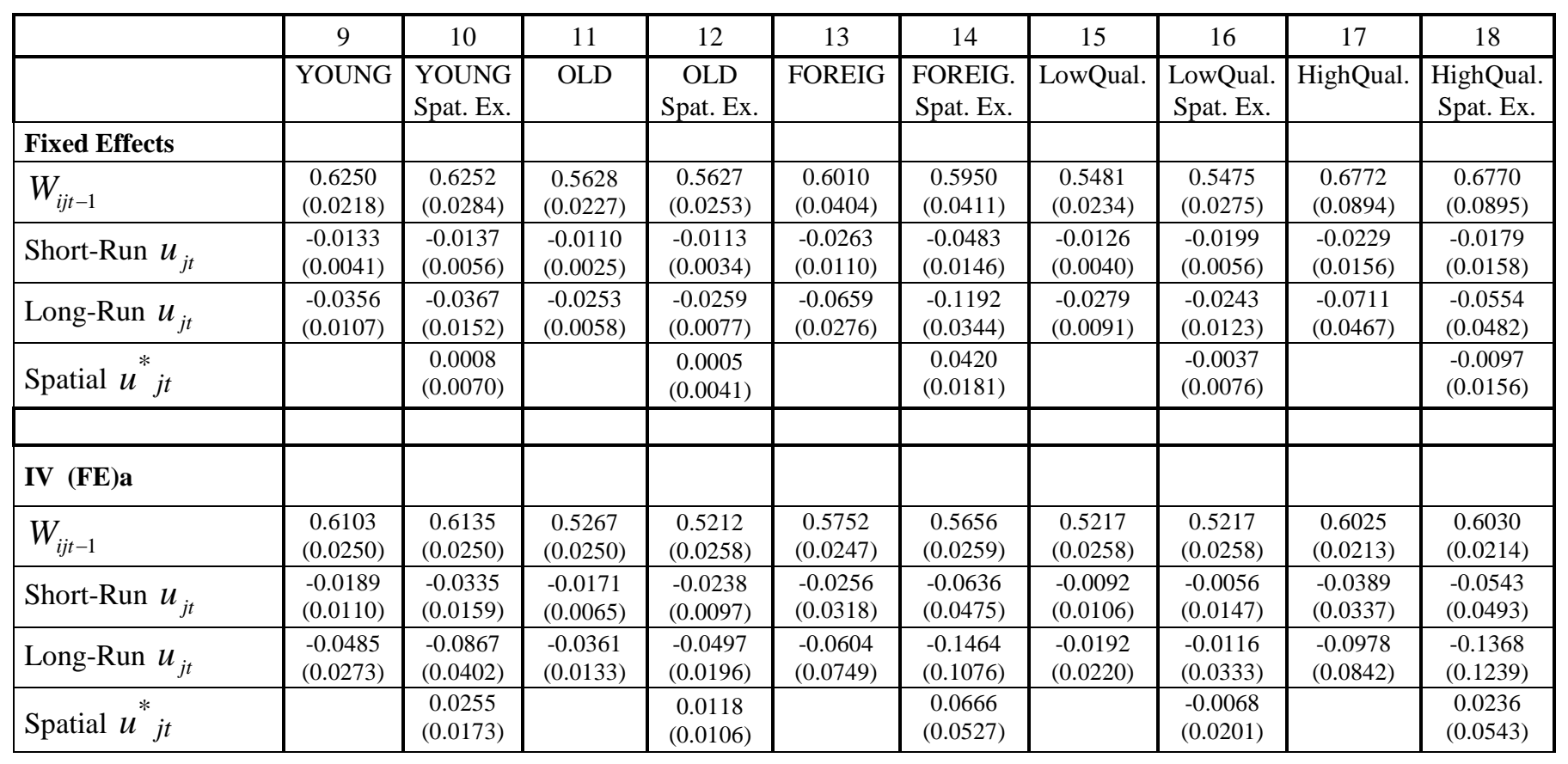

a This instruments for unemployment and spatial unemployment by its lags, see Bell et al. (2002). 
Unlike Longhi et al. (2006), we do find a wage curve for all types of regions. In their case, the wage curve was not significant in agglomerations. In our case, the wage elasticity is always negative and significant. It is slightly higher in absolute value for rural areas, see Table 4. This is -0.023 in the short run and -0.047 in the long run (for all employees and without spatial weighted unemployment). Therefore, the findings correspond to the hypothesis about local monopsony. Whereas in agglomerations workers have a choice between different firms, they depend to a relatively high degree on a single firm in rural areas. Under these conditions firms are more likely to enforce their claims than under the pressure of competing firms.

Spatial weighted unemployment is not significant for all employees and for most subgroups. One main exception is the labour market of males in the rural country (Table 4, Model 4). In this case, the wage elasticity due to the short run local unemployment rate increases from -0.024 to -0.035 and the wage elasticity due to the long run local unemployment elasticity from -0.048 to -0.071 . However, the spatial weighted unemployment elasticity is positive and significant (0.020). The same phenomenon of positive spatial weighted unemployment elasticity was also reported by Longhi et al. (2006).

One explanation of this result is that the unemployment rates of neighbouring regions are highly correlated. Between variables in levels, the correlation is 0.85 , between variables after carrying out the withintransformation, it is 0.95 . This might prevent a complete separation of the influences of local and spatial unemployment, in spite of the long panel we use.

Focusing on German versus Foreign, we notice a drastic increase in the wage elasticity when we introduce spatial weighted unemployment effects for foreign workers in regions with core cities. This elasticity in Table 2 for core cities goes up from -0.018 to -0.051 in the short run, and -0.030 to -0.082 in the long run. However, the spatial weighted unemployment elasticity is positive and significant (0.054). 
Table 5: Different spatial weighting matrices in models for different region types

Dynamic models of the wage curve with fixed effects

G1: Based on contiguity

G2: Based on commuting flows

G3: Based on distance (inverse)

G4: Based on traveling time ( $=0$ if $>1$ hour)

G5: Based on employment weighted contiguity

\begin{tabular}{|c|c|c|c|c|c|c|c|c|c|c|}
\hline & 1 & 2 & 3 & 4 & 5 & 6 & 7 & 8 & 9 & 10 \\
\hline & $\begin{array}{l}\text { ALL } \\
\text { G1 }\end{array}$ & $\begin{array}{l}\text { ALL } \\
\text { G2 }\end{array}$ & $\begin{array}{l}\text { ALL } \\
\text { G3 }\end{array}$ & $\begin{array}{l}\text { ALL } \\
\text { G4 }\end{array}$ & $\begin{array}{c}\text { ALL } \\
\text { G5 }\end{array}$ & $\begin{array}{c}\text { Typ1 } \\
\text { G1 }\end{array}$ & $\begin{array}{l}\text { Typ1 } \\
\text { G2 }\end{array}$ & $\begin{array}{l}\text { Typ1 } \\
\text { G3 }\end{array}$ & $\begin{array}{l}\text { Typ1 } \\
\text { G4 }\end{array}$ & $\begin{array}{c}\text { Typ } 1 \\
\text { G5 }\end{array}$ \\
\hline \multicolumn{11}{|l|}{ Fixed Effects } \\
\hline$W_{i j t-1}$ & $\begin{array}{c}0.5812 \\
(0.0135)\end{array}$ & $\begin{array}{c}0.5816 \\
(0.0135)\end{array}$ & $\begin{array}{c}0.5813 \\
(0.0135) \\
\end{array}$ & $\begin{array}{c}0.5817 \\
(0.0135) \\
\end{array}$ & $\begin{array}{c}0.5812 \\
(0.0130)\end{array}$ & $\begin{array}{c}0.5614 \\
(0.0221)\end{array}$ & $\begin{array}{c}0.5618 \\
(0.0221)\end{array}$ & $\begin{array}{c}0.5613 \\
(0.0222)\end{array}$ & $\begin{array}{c}0.5617 \\
(0.0222)\end{array}$ & $\begin{array}{c}0.5618 \\
(0.0261) \\
\end{array}$ \\
\hline Short-Run $u_{j t}$ & $\begin{array}{l}-0.0111 \\
(0.0014)\end{array}$ & $\begin{array}{l}-0.0127 \\
(0.0014)\end{array}$ & $\begin{array}{l}-0.0116 \\
(0.0014)\end{array}$ & $\begin{array}{l}-0.0123 \\
(0.0013)\end{array}$ & $\begin{array}{l}-0.0109 \\
(0.0019)\end{array}$ & $\begin{array}{l}-0.0098 \\
(0.0020)\end{array}$ & $\begin{array}{l}-0.0117 \\
(0.0019)\end{array}$ & $\begin{array}{c}-0.0102 \\
(0.0020)\end{array}$ & $\begin{array}{l}-0.0115 \\
(0.0018)\end{array}$ & $\begin{array}{l}-0.0107 \\
(0.0024)\end{array}$ \\
\hline Long-Run $u_{j t}$ & $\begin{array}{l}-0.0264 \\
(0.0033) \\
\end{array}$ & $\begin{array}{l}-0.0305 \\
(0.0034) \\
\end{array}$ & $\begin{array}{c}-0.0278 \\
(0.0034) \\
\end{array}$ & $\begin{array}{c}-0.0294 \\
(0.0031) \\
\end{array}$ & $\begin{array}{c}-0.0261 \\
(0.0046) \\
\end{array}$ & $\begin{array}{l}-0.0223 \\
(0.0046) \\
\end{array}$ & $\begin{array}{l}-0.0267 \\
(0.0044) \\
\end{array}$ & $\begin{array}{l}-0.0233 \\
(0.0047) \\
\end{array}$ & $\begin{array}{l}-0.0261 \\
(0.0042) \\
\end{array}$ & $\begin{array}{l}-0.0244 \\
(0.0052) \\
\end{array}$ \\
\hline Spatial $u^{*} j t$ & $\begin{array}{l}-0.0006 \\
(0.0017) \\
\end{array}$ & $\begin{array}{c}0.0025 \\
(0.0019) \\
\end{array}$ & $\begin{array}{l}-0.0003 \\
(0.0017) \\
\end{array}$ & $\begin{array}{c}0.0017 \\
(0.0017) \\
\end{array}$ & $\begin{array}{l}-0.0008 \\
(0.0022)\end{array}$ & $\begin{array}{c}-0.0031 \\
(0.0024) \\
\end{array}$ & $\begin{array}{c}0.0001 \\
(0.0027) \\
\end{array}$ & $\begin{array}{l}-0.0023 \\
(0.0025) \\
\end{array}$ & $\begin{array}{c}-0.0004 \\
(0.0026) \\
\end{array}$ & $\begin{array}{l}-0.0016 \\
(0.0029)\end{array}$ \\
\hline \multicolumn{11}{|l|}{ IV (FE) } \\
\hline$W_{i j t-1}$ & $\begin{array}{c}0.5527 \\
(0.0109) \\
\end{array}$ & $\begin{array}{c}0.5512 \\
(0.0109) \\
\end{array}$ & $\begin{array}{c}0.5523 \\
(0.0109) \\
\end{array}$ & $\begin{array}{c}0.5521 \\
(0.0109)\end{array}$ & $\begin{array}{c}0.5530 \\
(0.0109)\end{array}$ & $\begin{array}{c}0.5228 \\
(0.0186) \\
\end{array}$ & $\begin{array}{c}0.5227 \\
(0.0185)\end{array}$ & $\begin{array}{c}0.5224 \\
(0.0186)\end{array}$ & $\begin{array}{c}0.5214 \\
(0.0186) \\
\end{array}$ & $\begin{array}{c}0.5244 \\
(0.0186)\end{array}$ \\
\hline Short-Run $u_{j t}$ & $\begin{array}{l}-0.0175 \\
(0.0030)\end{array}$ & $\begin{array}{l}-0.0201 \\
(0.0028)\end{array}$ & $\begin{array}{l}-0.0183 \\
(0.0031)\end{array}$ & $\begin{array}{l}-0.0187 \\
(0.0025)\end{array}$ & $\begin{array}{l}-0.0162 \\
(0.0028)\end{array}$ & $\begin{array}{l}-0.0154 \\
(0.0052)\end{array}$ & $\begin{array}{l}-0.0175 \\
(0.0045)\end{array}$ & $\begin{array}{l}-0.0155 \\
(0.0054)\end{array}$ & $\begin{array}{l}-0.0180 \\
(0.0045)\end{array}$ & $\begin{array}{l}-0.0149 \\
(0.0047)\end{array}$ \\
\hline Long-Run $u_{j t}$ & $\begin{array}{l}-0.0391 \\
(0.0065) \\
\end{array}$ & $\begin{array}{l}-0.0448 \\
(0.0061) \\
\end{array}$ & $\begin{array}{c}-0.0409 \\
(0.0071) \\
\end{array}$ & $\begin{array}{c}-0.0416 \\
(0.0075) \\
\end{array}$ & $\begin{array}{l}-0.0361 \\
(0.0065) \\
\end{array}$ & $\begin{array}{l}-0.0322 \\
(0.0107) \\
\end{array}$ & $\begin{array}{l}-0.0367 \\
(0.0092) \\
\end{array}$ & $\begin{array}{l}-0.0324 \\
(0.0109) \\
\end{array}$ & $\begin{array}{l}-0.0375 \\
(0.0096) \\
\end{array}$ & $\begin{array}{l}-0.0313 \\
(0.0094) \\
\end{array}$ \\
\hline Spatial $u^{*} j t$ & $\begin{array}{c}0.0020 \\
(0.0034)\end{array}$ & $\begin{array}{c}0.0064 \\
(0.0038) \\
\end{array}$ & $\begin{array}{c}0.0032 \\
(0.0036) \\
\end{array}$ & $\begin{array}{c}0.0043 \\
(0.0031) \\
\end{array}$ & $\begin{array}{c}0.0002 \\
(0.0032)\end{array}$ & $\begin{array}{l}-0.0056 \\
(0.0057) \\
\end{array}$ & $\begin{array}{l}-0.0026 \\
(0.0060)\end{array}$ & $\begin{array}{l}-0.0054 \\
(0.0060)\end{array}$ & $\begin{array}{l}-0.0031 \\
(0.0050)\end{array}$ & $\begin{array}{l}-0.0059 \\
(0.0052) \\
\end{array}$ \\
\hline
\end{tabular}

\begin{tabular}{|c|c|c|c|c|c|c|c|c|c|c|}
\hline & 11 & 12 & 13 & 14 & 15 & 16 & 17 & 18 & 19 & 20 \\
\hline & $\begin{array}{c}\text { Typ2 } \\
\text { G1 }\end{array}$ & $\begin{array}{c}\text { Typ2 } \\
\text { G2 }\end{array}$ & $\begin{array}{c}\text { Typ2 } \\
\text { G3 }\end{array}$ & $\begin{array}{c}\text { Typ2 } \\
\text { G4 }\end{array}$ & $\begin{array}{c}\text { Typ2 } \\
\text { G5 }\end{array}$ & $\begin{array}{c}\text { Typ3 } \\
\text { G1 }\end{array}$ & $\begin{array}{c}\text { Typ3 } \\
\text { G2 }\end{array}$ & $\begin{array}{c}\text { Typ3 } \\
\text { G3 }\end{array}$ & $\begin{array}{c}\text { Typ3 } \\
\text { G4 }\end{array}$ & $\begin{array}{c}\text { Typ3 } \\
\text { G5 }\end{array}$ \\
\hline \multicolumn{11}{|l|}{ Fixed Effects } \\
\hline$W_{i j t-1}$ & $\begin{array}{c}0.5896 \\
(0.0207)\end{array}$ & $\begin{array}{c}0.5902 \\
(0.0207)\end{array}$ & $\begin{array}{c}0.5896 \\
(0.0207)\end{array}$ & $\begin{array}{c}0.5903 \\
(0.0207)\end{array}$ & $\begin{array}{c}0.5892 \\
(0.0188)\end{array}$ & $\begin{array}{c}0.5643 \\
(0.0285)\end{array}$ & $\begin{array}{c}0,5649 \\
(0.0288)\end{array}$ & $\begin{array}{c}0.5643 \\
(0.0285)\end{array}$ & $\begin{array}{c}0,5636 \\
(0.0288)\end{array}$ & $\begin{array}{c}0.5642 \\
(0.0251)\end{array}$ \\
\hline Short-Run $u_{j t}$ & $\begin{array}{l}-0.0130 \\
(0.0021)\end{array}$ & $\begin{array}{c}-0.0146 \\
(0.0023)\end{array}$ & $\begin{array}{l}-0.0137 \\
(0.0021)\end{array}$ & $\begin{array}{c}-0.0144 \\
(0.0020)\end{array}$ & $\begin{array}{l}-0.0121 \\
(0.0027)\end{array}$ & $\begin{array}{c}-0.0098 \\
(0.0023)\end{array}$ & $\begin{array}{c}-0.0109 \\
(0.0031)\end{array}$ & $\begin{array}{c}-0.0098 \\
(0.0032)\end{array}$ & $\begin{array}{c}-0.0099 \\
(0.0028)\end{array}$ & $\begin{array}{c}-0.0096 \\
(0.0057)\end{array}$ \\
\hline Long-Run $u_{j t}$ & $\begin{array}{l}-0.0318 \\
(0.0050)\end{array}$ & $\begin{array}{c}-0.0357 \\
(0.0056)\end{array}$ & $\begin{array}{l}-0.0335 \\
(0.0052)\end{array}$ & $\begin{array}{c}-0.0351 \\
(0.0048)\end{array}$ & $\begin{array}{l}-0.0295 \\
(0.0067)\end{array}$ & $\begin{array}{l}-0.0224 \\
(0.0073)\end{array}$ & $\begin{array}{c}-0.0250 \\
(0.0074)\end{array}$ & $\begin{array}{l}-0.0226 \\
(0.0075)\end{array}$ & $\begin{array}{l}-0.0226 \\
(0.0068)\end{array}$ & $\begin{array}{l}-0.0219 \\
(0.0135)\end{array}$ \\
\hline Spatial $u^{*}{ }^{\prime} t$ & $\begin{array}{c}0.0009 \\
(0.0025) \\
\end{array}$ & $\begin{array}{c}0.0041 \\
(0.0030)\end{array}$ & $\begin{array}{c}0.0020 \\
(0.0026) \\
\end{array}$ & $\begin{array}{c}0.0040 \\
(0.0026) \\
\end{array}$ & $\begin{array}{l}-0.0008 \\
(0.0028)\end{array}$ & $\begin{array}{c}-0.0023 \\
(0.0040) \\
\end{array}$ & $\begin{array}{c}-0.0002 \\
(0.0045) \\
\end{array}$ & $\begin{array}{c}-0.0021 \\
(0.0041) \\
\end{array}$ & $\begin{array}{c}-0.0026 \\
(0.0040) \\
\end{array}$ & $\begin{array}{l}-0.0027 \\
(0.0070)\end{array}$ \\
\hline & & & & & & & & & & \\
\hline \multicolumn{11}{|l|}{ IV (FE) } \\
\hline$W_{i j t-1}$ & $\begin{array}{c}0.5758 \\
(0.0161)\end{array}$ & $\begin{array}{c}0.5743 \\
(0.0162)\end{array}$ & $\begin{array}{c}0.5751 \\
(0.0162)\end{array}$ & $\begin{array}{c}0.5753 \\
(0.0161)\end{array}$ & $\begin{array}{c}0.5760 \\
(0.0161)\end{array}$ & $\begin{array}{c}0.5144 \\
(0.0260)\end{array}$ & $\begin{array}{c}0.5194 \\
(0.0261)\end{array}$ & $\begin{array}{c}0.5153 \\
(0.0260)\end{array}$ & $\begin{array}{c}0.5170 \\
(0.0260)\end{array}$ & $\begin{array}{c}0.5146 \\
(0.0260)\end{array}$ \\
\hline Short-Run $u_{j t}$ & $\begin{array}{l}-0.0155 \\
(0.0040)\end{array}$ & $\begin{array}{l}-0.0170 \\
(0.0039)\end{array}$ & $\begin{array}{c}-0.0160 \\
(0.0042)\end{array}$ & $\begin{array}{l}-0.0163 \\
(0.0033)\end{array}$ & $\begin{array}{l}-0.0137 \\
(0.0038)\end{array}$ & $\begin{array}{c}-0.0323 \\
(0.0084)\end{array}$ & $\begin{array}{c}-0.0358 \\
(0.0080)\end{array}$ & $\begin{array}{l}-0.0331 \\
(0.0086)\end{array}$ & $\begin{array}{l}-0.0322 \\
(0.0073)\end{array}$ & $\begin{array}{l}-0.0320 \\
(0.0083)\end{array}$ \\
\hline Long-Run $u_{j t}$ & $\begin{array}{c}-0.0366 \\
(0.0092)\end{array}$ & $\begin{array}{c}-0.0400 \\
(0.0090)\end{array}$ & $\begin{array}{l}-0.0376 \\
(0.0100)\end{array}$ & $\begin{array}{c}-0.0384 \\
(0.0095)\end{array}$ & $\begin{array}{r}-0.0323 \\
(0.0091)\end{array}$ & $\begin{array}{l}-0.0665 \\
(0.0167)\end{array}$ & $\begin{array}{c}-0.0744 \\
(0.0161)\end{array}$ & $\begin{array}{l}-0.0683 \\
(0.0172)\end{array}$ & $\begin{array}{c}-0.0667 \\
(0.0168)\end{array}$ & $\begin{array}{c}-0.0659 \\
(0.0170)\end{array}$ \\
\hline Spatial $u^{*}{ }_{j t}$ & $\begin{array}{c}0.0038 \\
(0.0051)\end{array}$ & $\begin{array}{c}0.0061 \\
(0.0055)\end{array}$ & $\begin{array}{c}0.0043 \\
(0.0053)\end{array}$ & $\begin{array}{c}0.0062 \\
(0.0045)\end{array}$ & $\begin{array}{c}0.0008 \\
(0.0048)\end{array}$ & $\begin{array}{c}0.0164 \\
(0.0091)\end{array}$ & $\begin{array}{c}0.0285 \\
(0.0107)\end{array}$ & $\begin{array}{c}0.0179 \\
(0.0094)\end{array}$ & $\begin{array}{c}0.0181 \\
(0.0089)\end{array}$ & $\begin{array}{c}0.0158 \\
(0.0086)\end{array}$ \\
\hline
\end{tabular}


Table 5 gives a robustness check with respect to four alternative choices of the weight matrix. The effect of spatial unemployment might depend on the special version of the spatial weight matrix used. Therefore, the matrix $G$ is varied in these checks: $G 1$ is the contiguity weight matrix used in Tables 1-4. G2 is based on commuting flows between regions, which is measured in relation to all employment in the respective target region. ${ }^{2}$ The proportion of commuters from one region to another is again row-normalised. This matrix gives linkages between regions which are farther apart, whereas G1 describes only adjacent neighbours. The matrix G3 is calculated by using the inverse of geographical distance between regions. This measure is calculated for the adjacent neighbours and is set to zero for all regions which have no common border. In G4, regions that could be reached within an hour have a weight of 1 and all others a weight of 0 . With G3 and G4 the regions are represented by their political centres which are mostly identical with the largest cities or towns of these regions. Finally, a matrix 65 based on contiguity is used again, but now the individual matrix elements are weighted according to employment in the respective region. This is done to give densely populated regions with agglomerated economies an adequate weight in the regressions.

Table 5 shows the empirical results are robust to the five weight matrices applied. The dynamic effect is positive and significant ranging between 0.51 to 0.58 depending on the spatial weight matrix used. Only slight differences in the estimates of the short-run unemployment effects are observed. These varied between (-0.01 and -0.03) depending on the spatial weight matrix used. Similarly, there were only slight differences in the estimates of the long-run unemployment effects. These varied between (-0.03 and -0.07) depending on the spatial weight matrix used. Spatial unemployment effects are mostly not significant no matter what spatial weight matrix is used. The only exception concerns regions from the rural country (type 3). Here, some of the spatial effects obtained with different weight matrices are in fact positive and significant. Since the corresponding local unemployment rate has a relatively larger negative and significant effect, a wage curve is still in existence.

2 This G2 matrix is the most susceptible to endogeneity problems, but we include it here for robustness check. 


\section{Table 6: Shortening the observation period}

German dynamic wage curve by type of region including spatial effects of unemployment The IAB Employment Sample: 1989-2004, spatial weight matrix G1

\begin{tabular}{|c|c|c|c|c|c|c|c|c|}
\hline & 1 & 2 & 3 & 4 & 5 & 6 & 7 & 8 \\
\hline & \multicolumn{2}{|c|}{$\begin{array}{c}\text { ALL } \\
\mathrm{N}=7824\end{array}$} & \multicolumn{2}{|c|}{$\begin{array}{l}\text { Only regions with } \\
\text { core cities }\end{array}$} & \multicolumn{2}{|c|}{$\begin{array}{c}\text { Regions with } \\
\text { conurbational. features }\end{array}$} & \multicolumn{2}{|c|}{$\begin{array}{l}\text { Regions in the rural } \\
\text { country }\end{array}$} \\
\hline \multicolumn{9}{|l|}{ Fixed Effects } \\
\hline$W_{i j t-1}$ & $\begin{array}{c}0.4725 \\
(0.0193) \\
\end{array}$ & $\begin{array}{c}0.4717 \\
(0.0190)\end{array}$ & $\begin{array}{c}0.4650 \\
(0.0311)\end{array}$ & $\begin{array}{c}0.4627 \\
(0.0303)\end{array}$ & $\begin{array}{c}0.4994 \\
(0.0243)\end{array}$ & $\begin{array}{c}0.4989 \\
(0.0240) \\
\end{array}$ & $\begin{array}{c}0.3551 \\
(0.0405) \\
\end{array}$ & $\begin{array}{c}0.3550 \\
(0.0385) \\
\end{array}$ \\
\hline Short-Run $u_{j t}$ & $\begin{array}{l}-0.0148 \\
(0.0018)\end{array}$ & $\begin{array}{l}-0.0108 \\
(0.0026)\end{array}$ & $\begin{array}{l}-0.0142 \\
(0.0022)\end{array}$ & $\begin{array}{l}-0.0086 \\
(0.0034)\end{array}$ & $\begin{array}{l}-0.0187 \\
(0.0028)\end{array}$ & $\begin{array}{l}-0.0154 \\
(0.0042)\end{array}$ & $\begin{array}{l}-0.0095 \\
(0.0041)\end{array}$ & $\begin{array}{l}-0.0061 \\
(0.0058)\end{array}$ \\
\hline Long-Run $u_{j t}$ & $\begin{array}{l}-0.0281 \\
(0.0035)\end{array}$ & $\begin{array}{l}-0.0204 \\
(0.0050)\end{array}$ & $\begin{array}{l}-0.0265 \\
(0.0044)\end{array}$ & $\begin{array}{l}-0.0160 \\
(0.0064)\end{array}$ & $\begin{array}{l}-0.0374 \\
(0.0062)\end{array}$ & $\begin{array}{l}-0.0308 \\
(0.0085)\end{array}$ & $\begin{array}{l}-0.0148 \\
(0.0062)\end{array}$ & $\begin{array}{l}-0.0094 \\
(0.0087)\end{array}$ \\
\hline Spatial $u^{*}{ }_{j t}$ & & $\begin{array}{l}-0.0070 \\
(0.0028)\end{array}$ & & $\begin{array}{l}-0.0095 \\
(0.0042)\end{array}$ & & $\begin{array}{l}-0.0059 \\
(0.0043)\end{array}$ & & $\begin{array}{l}-0.0078 \\
(0.0072)\end{array}$ \\
\hline \multicolumn{9}{|l|}{ IV $(F E)^{a}$} \\
\hline$W_{i j t-1}$ & $\begin{array}{c}0.4562 \\
(0.0149) \\
\end{array}$ & $\begin{array}{c}0.4577 \\
(0.0149)\end{array}$ & $\begin{array}{c}0.4533 \\
(0.0242)\end{array}$ & $\begin{array}{c}0.4530 \\
(0.0239)\end{array}$ & $\begin{array}{c}0.4953 \\
(0.0220)\end{array}$ & $\begin{array}{c}0.4968 \\
(0.0220)\end{array}$ & $\begin{array}{c}0.3264 \\
(0.0360)\end{array}$ & $\begin{array}{c}0.3254 \\
(0.0369)\end{array}$ \\
\hline Short-Run $u_{j t}$ & $\begin{array}{l}-0.0226 \\
(0.0034)\end{array}$ & $\begin{array}{l}-0.0136 \\
(0.0064)\end{array}$ & $\begin{array}{l}-0.0208 \\
(0.0055)\end{array}$ & $\begin{array}{l}-0.0059 \\
(0.0113)\end{array}$ & $\begin{array}{l}-0.0205 \\
(0.0047)\end{array}$ & $\begin{array}{l}-0.0116 \\
(0.0085)\end{array}$ & $\begin{array}{l}-0.0299 \\
(0.0117)\end{array}$ & $\begin{array}{l}-0.0382 \\
(0.0175)\end{array}$ \\
\hline Long-Run $u_{j t}$ & $\begin{array}{l}-0.0415 \\
(0.0059) \\
\end{array}$ & $\begin{array}{l}-0.0250 \\
(0.0116) \\
\end{array}$ & $\begin{array}{l}-0.0380 \\
(0.0095) \\
\end{array}$ & $\begin{array}{l}-0.0107 \\
(0.0207) \\
\end{array}$ & $\begin{array}{l}-0.0406 \\
(0.0086) \\
\end{array}$ & $\begin{array}{c}-0.0231 \\
(0.0166) \\
\end{array}$ & $\begin{array}{c}-0.0444 \\
(0.0164) \\
\end{array}$ & $\begin{array}{c}-0.0567 \\
(0.0248) \\
\end{array}$ \\
\hline Spatial $u^{*} j t$ & & $\begin{array}{c}-0.0132 \\
(0.0071) \\
\end{array}$ & & $\begin{array}{l}-0.0207 \\
(0.0118)\end{array}$ & & $\begin{array}{l}-0.0137 \\
(0.0097)\end{array}$ & & $\begin{array}{c}0.0169 \\
(0.0189) \\
\end{array}$ \\
\hline
\end{tabular}

Table 6 re-estimates our model using a shortened time period 1989-2004. We use the year of German unification as the new starting point, since it is interesting to see whether this event had any visible effects on the relationship between regional unemployment and wages. ${ }^{3}$ After unification the influence of unions on wage setting decreased. The percentage of union members among West German employees decreased from $28.7 \%$ in 1992 to 21.7 \% in 2004 (Schnabel, Wagner 2007, see also Schnabel, Wagner 2003). Today, there are many firms not covered by a collective agreement on wages. Since most unions negotiate at the level of sectors not at the level of regions, this could mean that regional influences are more pronounced in later years. Less union coverage should contribute to a greater responsiveness of wages to local labour market conditions. Also, unemployment is expected to be high in regional labour markets with smaller flexibility.

The results of Table 6 for the shorter time span are similar in spirit to the results using the full sample, although the estimates and their standard errors are different. For dynamic panels with fixed effects, shortening the time span may introduce more bias. Comparing with the results in Tables 1-4, we see that dynamics are still significant even for this shorter time period, although with smaller magnitudes ( 0.36 to 0.50 ) rather than (0.56 to 0.59 ) in the earlier Tables. The short-run unemployment effect is -0.014 compared to -0.02 in Table 1 , while the long-run unemployment effects are -0.025 and -0.043 , respectively. All of which are significant. The spatial

${ }^{3}$ We would like to thank two referees for suggesting this sensitivity analysis to the period studied. 
unemployment effect is negative and significant (-0.013) for this shorter period when it was positive and insignificant (0.002) for the total sample. This spatial unemployment effect remains negative and significant for regions with large core cities $(-0.021)$ and regions with conurbational features (-0.014) but positive and insignificant for regions belonging to the rural country (0.017). Note, however, that the short-term effect of unemployment becomes insignificant for regions with large core cities and regions with conurbational features. This could be due to multicollinearity and the shorter period. In sum, Table 6 confirms that our results are sensitive to the period considered. However, the main effects are still in tact. Dynamics and regional unemployment effects are significant, however, they have different magnitudes depending on the period and type of region considered. We carried further sensitivity analysis (not reported here to save space) but covering the early years (from 1980 to 1994). In the basic wage curve without spatial effects, the unemployment elasticity of wages is -0.0116 in the short-run and -0.0212 in the long run and both are significant. These figures are only slightly smaller than the corresponding ones shown in Table 6. These results confirm that the wage curve in Germany is a 'shy guy' which is sensitive to the period considered. Table 6 also shows that spatial effects increased after unification except for rural areas. This is of course subject to the caveat that this is fixed effects dynamics panel estimation and is subject to bias for shorter length time period.

\section{Conclusion}

Using models with spatial interactions, this study reconsiders the empirical evidence on the western German wage curve. One main focus is the application of dynamic models which are augmented by a spatially weighted unemployment rate. In addition, central aspects concerning agglomeration effects and the differentiation between various subpopulations are considered. Our primary data base is the IAB Employment Sample (IABS) over the period 1980-2004. This micro data set allows us to control for individual unobserved heterogeneity.

We confirm the finding of a dynamic wage curve, i.e. a significant coefficient on lagged wages (about 0.55) that is far from unity. The wage elasticity with respect to unemployment is relatively small but significant $(-0.016)$ in the short run and about double (-0.037) in the long run. We also find that this wage effect of unemployment is more pronounced for groups with weaker bargaining power, i.e. younger versus older workers, men versus women, foreigners versus native Germans. This corresponds closely to theoretical expectations.

Important results are obtained for different types of regions. It can be seen that the wage curve in the rural country is more elastic than that in core cities and large agglomerations. This can be attributed to the degree of monopsony in the labour market. In large agglomerations, firms have more competitors, whereas in the rural country the dependency of workers on single firms is more pronounced. 
It is remarkable that the spatially weighted unemployment rate is only seldom important for the level of wages. In most of our results, only local unemployment influences wages. Again the rural country is a counterexample. While this is our finding for West Germany, spatial unemployment could be significant for other countries where wage negotiations and labour markets are different.

\section{References}

Baltagi, Badi H.; Blien, Uwe; Wolf, Katja (2009): “New Evidence on the Dynamic Wage Curve for Western Germany: 1980-2004”, in: Labour Economics 16/1: 47-51

Bell, Brian; Nickell, Stephen; Quintini, Glenda (2002): "Wage equations, wage curves and all that", in: Labour Economics 9: 341-360

Blanchflower, David G.; Oswald, Andrew J. (1994): "The Wage Curve", Cambridge (Mass.), London: MIT Press

Blanchflower, David G.; Oswald, Andrew J. (2005): "The wage curve reloaded", NBER Working Paper 11338

Bruecker, Herbert; Jahn, Elke J. (2010): "Migration and Wage-Setting: Reassessing the Labor Market Effects of Migration", in: Scandinavian Journal of Economics (forthcoming)

Buettner, Thiess (1999): "The effect of unemployment, aggregate wages, and spatial contiguity on local wages: An investigation with German district level data", in: Papers in Regional Science 78/1: 47-67

Card, David (1995): "The Wage Curve: A Review", in: Journal of Economic Literature 33/2: 785-799

Longhi, Simonetta; Nijkamp, Peter; Poot, Jacques (2006): "Spatial Heterogeneity and the Wage Curve Revisited", in: Journal of Regional Science 46/4: 707-731

Manning, Alan (2003): "Monopsony in Motion. Imperfect Competition in Labour Markets", Princeton: Princeton University

Manning, Alan (2004): "Monopsony and the efficiency of labour market interventions", in: Labour Economics 11/2: $145-160$

Ottaviano, Gianmarco; Peri, Giovanni (2006): "Rethinking the Effects of Immigration on Wages", NBER Working Paper 12497

Pannenberg, Markus; Schwarze, Johannes (2000): "Wage Dynamics and Unemployment in Germany: Evidence from Regional Panel Data", in: Labour 14: 645-655

Rubin, Donald B. (1987): "Multiple Imputation for Nonresponse in Surveys", New York etc.: John Wiley \& Sons 
Rubin, Donald B. (1996): "Multiple Imputation After 18+ Years", in: Journal of the American Statistical Association 91/434: 473-489

Schnabel, Claus, Wagner, Joachim (2003): "Trade Union Membership in Eastern and Western Germany: Convergence or Divergence?", in: Applied Economics Quarterly 49: 213-232.

Schnabel, Claus, Wagner, Joachim (2007), "The persistent decline in unionization in western and eastern Germany, 1980-2004: What can we learn from a decomposition analysis?", in: Industrielle Beziehungen 14/2: 118-132 